\title{
Cisplatin stimulates the expression from the human immunodeficiency virus long terminal repeat sequences in human fibroblasts
}

\author{
V Zoumpourlis, P Patsilinacos, A Kotsinas, \\ HR Maurer, P Lenas and DA Spandidos ${ }^{\mathrm{CA}}$ \\ All authors except HR Maurer are at the Institute of \\ Biological Research and Biotechnology, National \\ Hellenic Research Foundation, 48 Vas, Constantinou \\ Ave., Athens, 11635, Greece. HR Maurer is at the Institut \\ für Pharmazie der Freien Universität Berlin, Kelchstr. 31, \\ 1000 Berlin 41, Germany. DA Spandidos is also at \\ the Medical School, University of Crete, Heraklion, \\ Greece.
}

previously shown that cisplatin transcriptionally activates the HIV LTR sequences in rat fibroblasts. ${ }^{6}$ In the present study we have examined the effect of cisplatin on the HIV LTR in human fibroblasts and found that cisplatin also stimulates transcriptional activation significantly in this system.

\section{Materials and methods}

\section{Recombinant plasmids and cell lines}

Plasmid pBHIV1 was derived from plasmid $\mathrm{pBC} 12 / \mathrm{HIV} / \mathrm{CAT}^{7}$ by inserting a $1.9 \mathrm{~kb} \mathrm{BamH1}$ fragment carrying the aph gene into the single Bam $\mathrm{H} 1$ site. Plasmid pBC12/HIV/CAT carries a 728 bp XhoI-HindIII DNA fragment containing the HIV LTR sequences linked to the CAT reporter gene.

The MRCSV40TGR human fibroblasts were obtained after immortalization of MRC cells with SV40 and are resistant to 6-thioguanine. SVTGHIV1-1 cells were obtained after transfection with plasmid pBHIV1 and selection in the presence of geneticin.

\section{CAT assays}

Cells were grown exponentially in Ham's medium containing $10 \%$ fetal calf serum and assayed for CAT activity as previously described. ${ }^{8}$

Assay for cell proliferation

The rapid colorimetric assay for cell proliferation of Mossmann ${ }^{9}$ was used as previously described. ${ }^{6}$

\footnotetext{
CA Corresponding Author
} 


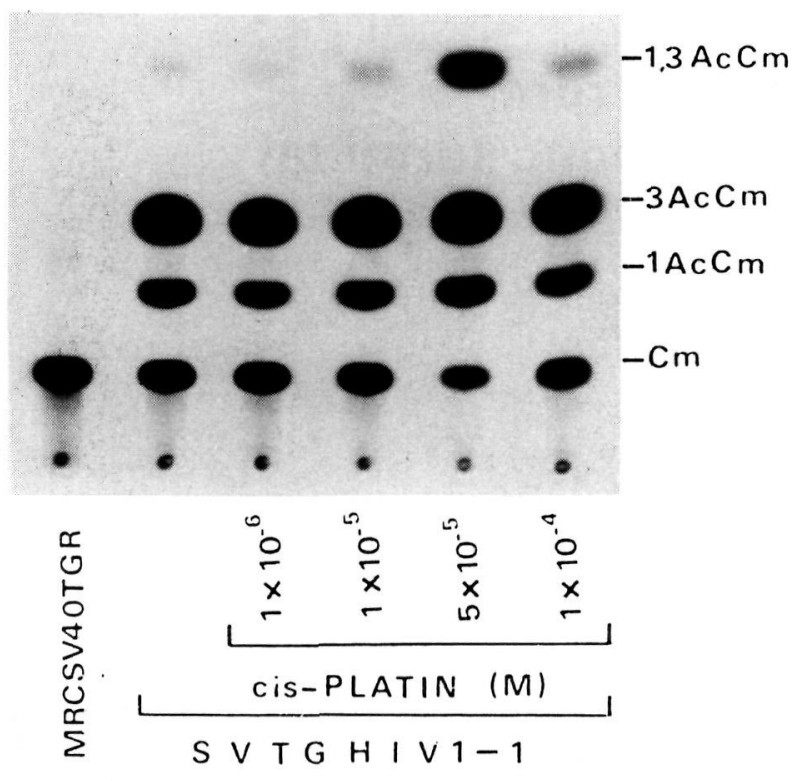

(a)

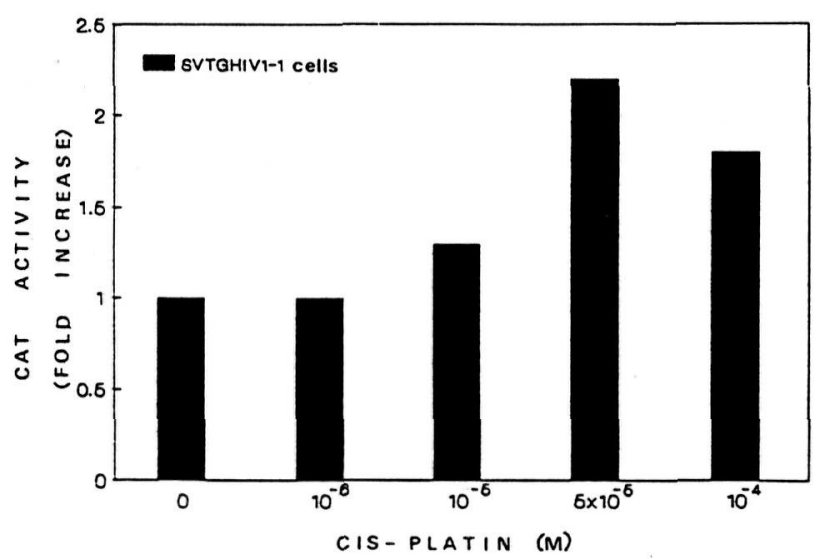

(b)

Figure 1. Induction of CAT activity by cisplatin. (a) Chromatogram of representative CAT assay with extracts from recipient MRCSV4OTGR and transfectant SVTGHIV11 cells with and without treatment with cisplatin. (b) Histogram of recorded CAT activities. MRCSV40TGR and SVTGHIV1-1 cells were plated at $1.5 \times 10^{6}$ cells $/ 75 \mathrm{~cm}^{2}$ flask in Ham's SF12 medium containing $10 \%$ FCS at $37^{\circ} \mathrm{C}$. $24 \mathrm{~h}$ later the medium was replaced with Ham's SF12 medium containing $0.5 \%$ FCS and left for another $24 \mathrm{~h}$ at $37^{\circ} \mathrm{C}$. The medium was then changed with Ham's SF12 containing 5\% FCS and the varying concentrations of cisplatin. Cells were harvested $24 \mathrm{~h}$ later and tested for CAT activity as described in Materials and methods. Relative values of CAT activity in SVTGHIV1-1 cells were 48 pmole acetylated chloramphenicol $/ \mu \mathrm{g}$ protein per hour incubation. Average from three experiments is given. Standard deviation was less than $5 \%$ of the average values.

\section{Results}

Cisplatin enhances transcription from the HIV LTR sequences

The recipient MRCSV40TGR and the transfectant SVTGHIV1-1 cells were treated with cisplatin at various concentrations. A representative CAT assay is shown in Figure 1(a) and the corresponding histogram in Figure 1(b). Optimal stimulation was obtained at $5 \times 10^{-5} \mathrm{M}$, where CAT activity increased 2.2-fold. As shown in Figure 2 a time course revealed that $24 \mathrm{~h}$ exposure to cisplatin gave rise to maximal activation.

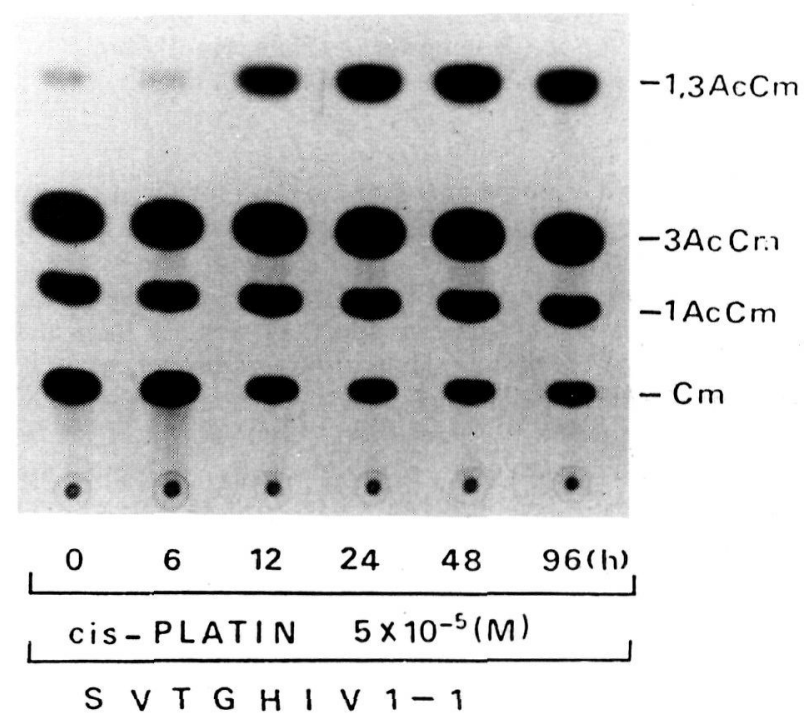

(a)

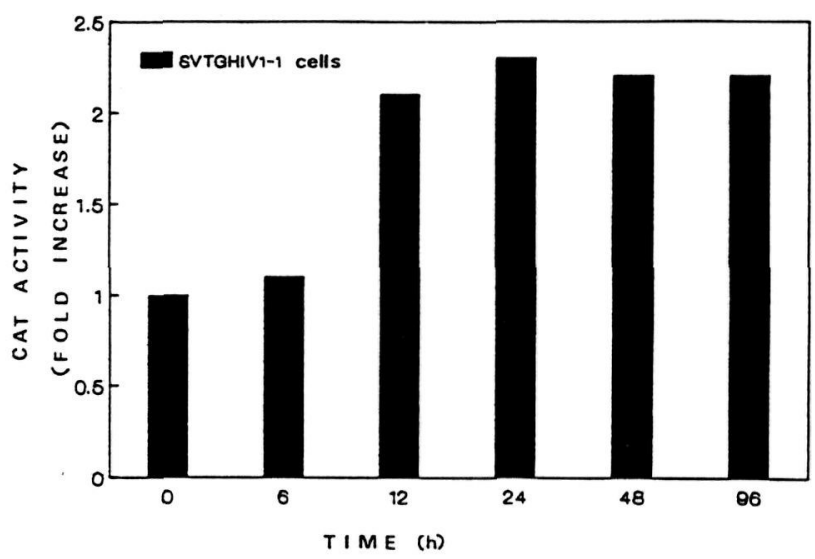

(b)

Figure 2. Induction of CAT activity in SVTGHIV1-1 cells by cisplatin at various times post-treatment. (a) Chromatogram for representative CAT assays with extracts from SVTGHIV1-1 cells treated with $5 \times 10^{-5} \mathrm{M}$ cisplatin at various times. (b) CAT values were computed and are presented in histograms as described in Figure 1. 


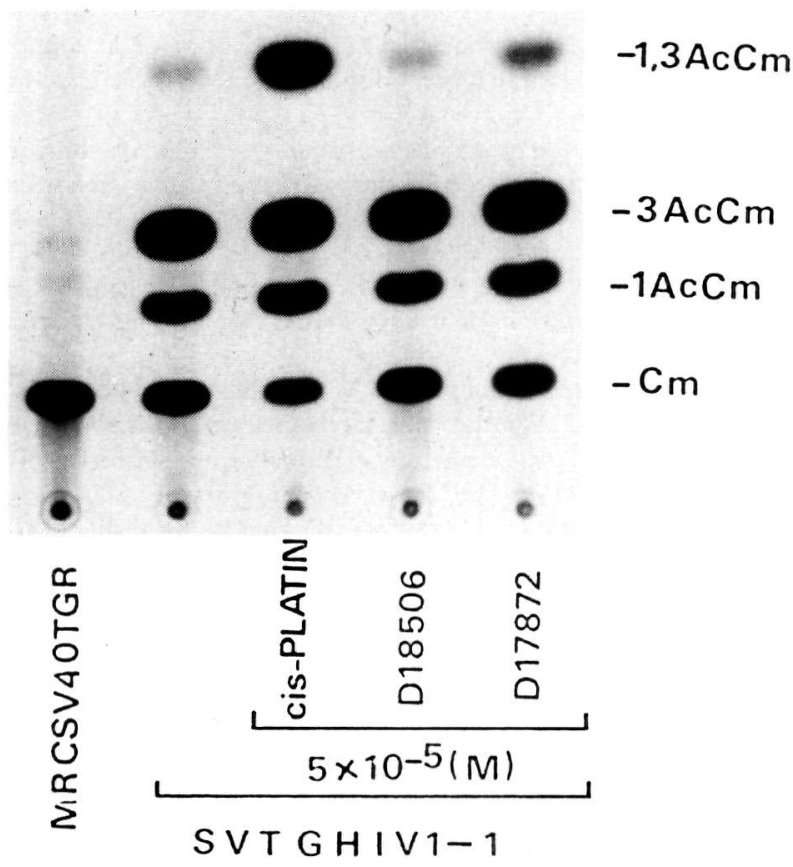

(a)

Effect of other anti-neoplastic compounds on HIV LTR activation

Two other compounds with known antineoplastic properties-D17872, a benzylethylenediamine derivative of cisplatin, ${ }^{10}$ and D18506, a hexadecyl-

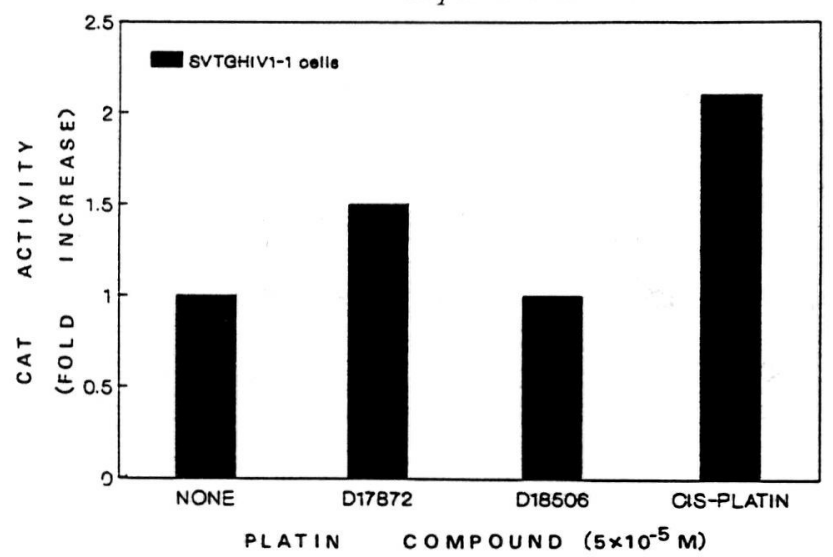

(b)

Figure 3 Induction of CAT activity by cisplatin and D17872 and D18506. (a) Chromatograms for representative CAT assays with extracts from SVTGHIV1-1 cells treated with $5 \times 10^{-5} \mathrm{M}$ cisplatin and the antineoplastic compounds D18506 and D17872. (b) CAT values were computed and are presented in histograms as described in Figure 1.

phosphocholine compound ${ }^{11}$ - were employed at concentrations similar to that of cisplatin $\left(5 \times 10^{-5}\right.$ M) to test their effect on HIV LTR activation. As shown in Figure 3, only the D17872 compound activated the HIV LTR at 1.7-fold, much below the activation caused by cisplatin.

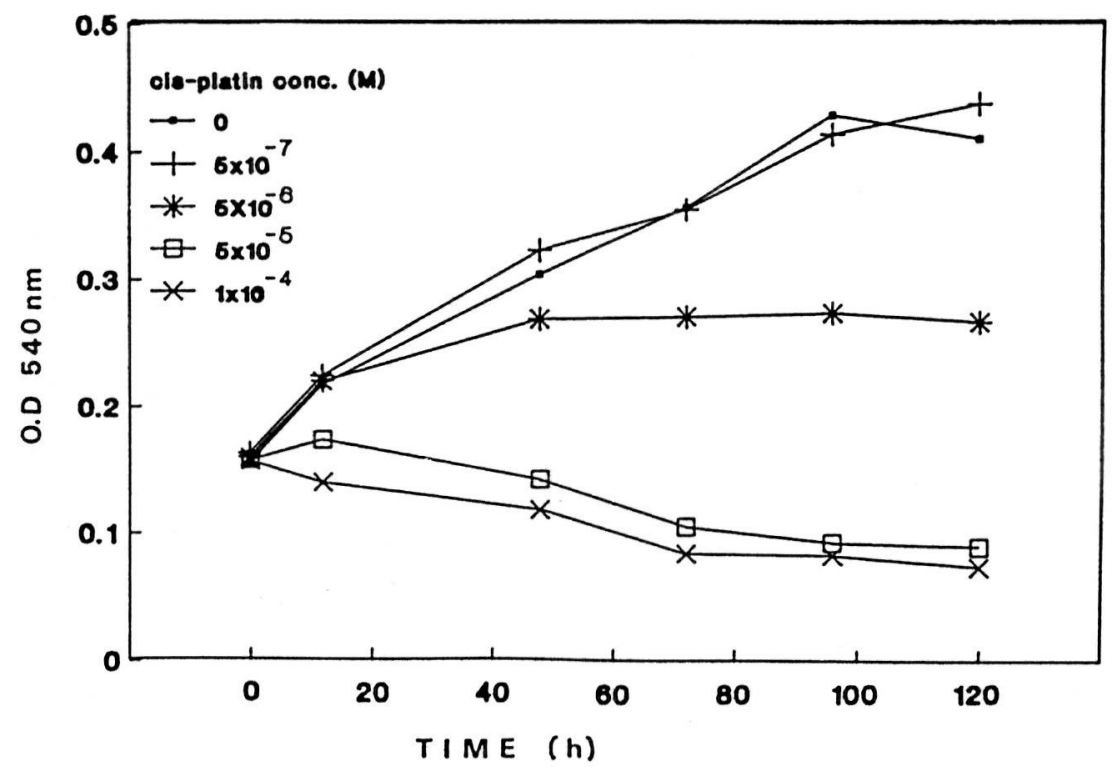

Figure 4. Cell proliferation in response to cisplatin at various times of exposure. $5 \times 10^{3}$ exponentially growing SVTGHIV1-1 cells were plated in 96-well tissue culture clusters (costar) in Ham's SF12 medium containing $10 \%$ FCS in the presence of the indicated concentration of cisplatin. At the indicated times cell proliferation was measured using Mossman's rapid colorimetric assay. ${ }^{9}$ 


\section{Cisplatin toxicity}

The effect of cisplatin on SVTGHIV1-1 cells was measured by a rapid cell proliferation assay. SVTGHIV1-1 cells were exposed for various times $(0,24,48,72,96,120 \mathrm{~h})$ at a range of concentrations of the drug (from $5 \times 10^{-7} \mathrm{M}$ to $1 \times 10^{-4} \mathrm{M}$ (Figure 4).

The same initial number of cells was used for each concentration. Toxicity was measured, using Mosmann's colorimetric MT'T assay. As seen in Figure 4, at the concentration where the cisplatin was most effective in stimulating the HIV LTR $\left(5 \times 10^{-5} \mathrm{M}\right)$ it was strongly inhibitory for cell proliferation.

\section{Discussion}

The human immunodeficiency virus LTR contains several defined regulatory domains. ${ }^{5}$ These can be cis- $^{12,13}$ or trans-acting sequences responding to cellular ${ }^{14}$ or viral ${ }^{15}$ gene products.

In a previous study we have found that cisplatin at $5 \times 10^{-5} \mathrm{M}$ concentrations stimulated by 22 -fold the expression of the reporter CAT gene from the HIV LTR in rat fibroblasts. ${ }^{6}$ In the present study we have found that in human fibroblasts cisplatin enhances the HIV LTR although at a much lower level (2.2-fold) (Figure 1). Again, it is of interest that the effect of cisplatin is observed when cell proliferation is strongly suppressed (Figure 4). Since cisplatin potentiates the activity of HIV LTR as shown before in rat, ${ }^{6}$ and as shown here in human, fibroblasts we urged further caution when considering therapy including this compound in the treatment of AIDS patients carrying tumors.

\section{References}

1. Rosenberg B, Van Camp L, Trosko JE, Mansour VH. Platinum compounds a new class of potent antitumour agents. Nature 1969; 222: 385-386.

2. Loehrer PJ, Einhorn LE. Cis-platin. Ann Internal Med 1984; 100: 704-713.
3. Roberts JJ, Thomson AJ. The mechanism of action of antitumour platinum compounds. Progress Nucl Acid Res 1979; 22: 71-133.

4. Cremer KJ, Spring SB, Gruber J. Role of human immunodeficiency virus type 1 and other acquired immunodeficiency disease syndrome. I Natl Cancer Inst 1990; 82: 1016-1024.

5. Hammazskjold M-L, Recosh D. The molecular biology of the human immunodeficiency virus. Biochim Biophys Acta 1989; 959: 269-280.

6. Spandidos DA, Zoumpourlis V, Kotsinas A, Maurer HR, Patsilinacos P. Transcriptional activation of the human immunodeficiency virus long terminal repeat sequences by cis-platin. Genetic Anal Techn Appl (in press).

7. Berger J, Hamber J, Hamber R, Geiger R, Cullen BR. Secreted placental alkaline phosphatase: a powerful new quantitative indicator of gene expression in eukaryotic cells. Gene 1988; 66: 1-10.

8. Spandidos DA, Riggio M. Promoter and enhancer like activity at the $5^{\prime}$-end of normal and T24 Ha-ras 1 genes. FEBS Lett 1986; 203: 169-174.

9. Mosmann T. Rapid colorimetric assay for cellular growth and survival: application of proliferation and cytoxicity assays. J Immunolog Met. 1983; 65: 55-63.

10. Maurer HR, Echarti C, Voegeli R, Pohl J, Hilgard P. The antitumor activity of D17872 is associated with tumor cell differentiation. Cancer Chemoth Pharm (in press).

11. Voegeli R, Echarti C, Maurer HR, et al. Selective activity of hexadecylphosphocholine against tumor cell in vitro is paralleled by its anti-tumor activity in vitro. Eur $J$ Cancer Clin Oncology (in press).

12. Kaufman JD, Valandra G, Roderiguez G, Bushar G, Giri C, Norcross MA. Phorbol ester enhances human immunodeficiency virus-promoted gene expression and acts on a repeated 10-base-pair functional enhancer element. Mol Cell Biol 1987; 7: 3759-3766.

13. Rosen CA, Sodroski JG, Haseltine WA. The location of cis-acting regulatory sequences in the human $\mathrm{T}$ cell lymphotropic virus type III (HTLV-III/LAV) long terminal repeat. Cell 1985; 41: 813-823.

14. Spandidos DA, Yiagnisis M, Pintzas A. Human immunodeficiency virus long terminal repeat responds to transformation by the mutant T24 H-ras 1 oncogene and it contains multiple AP-1 binding TPA-inducible consensus sequence elements. Anticancer Res 1989; 9: 383-386.

15. Jakobovits A, Rosenthal A, Capon DJ. Trans-activation of HIV1-1 LTR-directed gene expression by tat requires protein kinase C. EMBO J 1990; 9: 1165-1170.

(Received 2 August 1990; accepted 23 August 1990) 